\title{
Growth of Preimplatation Bovine Embryos
}

\author{
By P. Lonergan
}

Department of Reproduction and Forensic Medicine, Norwegian College of Veterinary Medicine, Oslo, Norway.

\begin{abstract}
Lonergan, P.: Growth of preimplantation bovine embryos. Acta vet. scand. 1994, 307-320. - Development of mammalian embryos in vitro is functionally and temporally inferior to embryo development as it occurs inside the female reproductive tract. The deficiencies of cultured embryos range from slow cleavage rates to complete developmental arrests or blocks, occurring at particular stages in many species. A variety of approaches have been used to overcome the blocks, including most extensively the coculture of preimplantation embryos with various somatic cells. However, even with coculture, development of embryos in vitro is still not equivalent to that in vivo. In most laboratories, only $25-40 \%$ of inseminated oocytes develop into morulae and blastocysts in spite of numerous variations on the basic technique. A better understanding of the factors governing embryonic growth is required before we can hope to achieve results comparable with those occurring in vivo.
\end{abstract}

cattle; cell cycle; in vitro; maturation; fertilization; culture.

\section{Introduction}

As pointed out by Kane et al. (1992), the preimplantation mammalian embryo is a fascinating biological entity: It contains the entire genomic information for the development of the adult animal. At the stage of transition from morula to blastocyst, it begins the complex process of differentiation leading to the formation of the adult animal. At the blastocyst stage it becomes capable of rapid growth, and in spite of the fact that it is foreign tissue, it escapes rejection by the maternal immune system.

Our knowledge of how to control preimplantation embryo development and growth is deficient in many aspects as evidenced by the great difficulty there is in growing embryos of many species in vitro while maintaining viability. However, with the advent of in vitro embryo production technology and the relatively unlimited supply of raw material, it is now possible to produce embryos in large numbers for research purposes.

\section{In vitro embryo production}

The techniques for producing bovine embryos from oocytes aspirated from slaughterhouse ovaries are now well established. However, the process is inefficient. At present, rates of bovine in vitro maturation (IVM) are high, as measured by attainment of metaphase II (MII) and in vitro fertilization (IVF) success ( $\geq 85 \%$ develop to 2 -cell stage). However, post-fertilization development of IVM/IVF ova is generally low, usually resulting in a yield of about $30-50 \%$ morulae/blastocysts and $20-40 \%$ blastocysts calculated as a proportion of all oocytes cultured (Pollard et al. 1989, Jiang et al. 1990, Kajihara et al. 1990, Younis \& Brackett 1990). It would appear that not all selected oocytes are fully capable of responding to the in vitro maturation conditions imposed upon them. The shortfall in developmental ability is most likely due to inadequacies in cytoplasmic maturation, a parameter which can not be routinely assessed after 
IVM, unlike the nuclear status of the oocyte. As pointed out by Rose \& Bavister (1992), inadequate oocyte maturation could underlie failure to cleave or abnormal embryo development. Although transfer of IVM/IVF embryos have produced live offspring, for practical reasons, a relatively small number of highly selected embryos are transferred, and the viability of the majority of embryos is unknown. The intrinsic viability of in vitro-produced bovine embryos appears to be inferior to those developed in vivo, as indicated by reduced cell numbers and poor survival following cryopreservation.

The following literature review is intended to give the reader some background information on the area of growth and differentiation in the preimplantation embryo, with the emphasis being placed on early bovine embryonic development.

\section{From one-cell to blastocyst}

\section{Resumption and completion of meiosis}

The meiotic cycle of mammalian oocytes is arrested during primordial development in prophase of the first meiotic division (G2 of the cell cycle) (Motlik \& Kubelka 1990). The large prophase nucleus (germinal vesicle) is diploid but $4 \mathrm{C}$ with regard to DNA content (i.e. 4 times the haploid DNA complement). The resumption and subsequent completion of the first meiotic division (i.e. progression from prophase I to metaphase II) is crucial for the maturation of the oocyte and is characterized by the extrusion of the first polar body, the reduction in DNA content from $4 \mathrm{C}$ to $2 \mathrm{C}$ (i.e. twice the haploid DNA complement), and the formation of a secondary oocyte. Sperm penetration of the oocyte results in the morphological and molecular changes that initiate the transition from a meiotic to a mitotic cell cycle by triggering the progression from metaphase II to anaphase II, with subsequent ejection of the second polar body and the establishment of a haploid maternal chromosomal complement. A diploid state is then re-established upon union of maternal and paternal chromosomes prior to first cleavage.

\section{Early development}

The early preimplantation period of embryonic life encompasses a number of significant events including: initiation and continuation of cleavage, activation of the embryonic genome, aggregation and compaction of the blastomeres, differentiation of the trophectoderm (TE) and inner cell mass (ICM), formation and expansion of the blastocoelic cavity, hatching from the zona pellucida, and in many species, extensive growth.

The transition of the mammalian embryo from a single cell to a multicellular blastocyst having 2 distinct cell compartments, the inner cell mass and the trophectoderm is a complex process. The one-cell mammalian embryo is a relatively large cell whose size varies with the species from about $70 \mu \mathrm{m}$ to $140 \mu \mathrm{m}$. Following fertilization, the first morphologically visible event in the preimplantation development is the initiation of cleavage, consisting of a series of cell divisions which progressively reduce cell size and the cytoplasmic nuclear ratio to that of a normal somatic cell (Kane 1990). Compaction of the blastomeres is a fundamental event in the development of the mammalian embryo involving the formation of tight junctions between adjacent blastomeres (Dubicella \& Anderson 1975). This process occurs at a certain time after fertilization (at the 32-64 cell stage in the bovine) and results in the loss of observable cell boundaries ( $\mathrm{Du}$ bicella \& Anderson 1975). Apart from being a prerequisite for the proper morphogenetic formation of the blastocyst (Hyafil et al. 1980 ), compaction also provides a visible sign that the embryo has overcome the in vitro 8- 
to 16-cell block (see below). The first cell differentiation occurs at the blastocyst stage with the development of the TE and ICM and the formation of a fluid-filled cavity, or blastocoel. The blastocoel arises from the presence of an ionic gradient formed between the outside and the inside of the blastocyst leading to the osmotic accumulation of fluid inside the embryo in intercellular spaces.

In vivo, at the time of transition from compact morula to blastocyst (between days 6 and 8 post insemination) the bovine embryo is approximately $160 \mu \mathrm{m}$ in diameter with a zona pellucida of approximately $12 \mu \mathrm{m}$ (Linares \& King 1980). At the early blastocyst stage, the embryo contains about 100 cells (Mannaerts 1986, Picard et al. 1986). Blastocysts with obvious blastocoels, but which have not yet fully expanded, contain about 120 cells, whereas fully expanded blastocysts, still within the zona but on the point of hatching, contain about 160 cells (Mannaerts 1986). At the time of hatching (between days 8 and $10 \mathrm{pi}$ ) the embryo has increased in size to approximately $280 \mu \mathrm{m}$ and contains approximately 200 cells. Thereafter, numbers increase rapidly and are correlated with the diameter of the spherical blastocyst.

\section{The cell cycle}

The cell cycle is composed of 2 distinct phases, $\mathrm{M}$ phase and interphase (Betteridge \& Flechon 1988). $M$ phase refers to the period of mitosis and entails karyokinesis and cytokinesis of a parent cell resulting in 2 daughter cells. Interphase is composed of 3 periods: $S$, which is the period when DNA replication is conducted, and G1 and G2, which comprise the gap periods between $\mathrm{M}$ and $\mathrm{S} ; \mathrm{G} 1=$ pre-replication and G2=post-replication. An exception to this general rule is the cell cycle of early cleaving embryos, which is characterized by a relative brevity or lack of gap phases, and therefore composed primarily of $\mathrm{M}$ phase and $\mathrm{S}$ to the time when the embryonic genome begins to be expressed (Barnes \& Eyestone 1990).

\section{In vivo data}

In vivo, the time required for progression to the first cleavage stage ranges from $23-31 \mathrm{~h}$ post-fertilization (Hamilton \& Laing 1946, Hyttel et al. 1988). However, as pointed out by Barnes \& Eyestone (1990), this does not accurately reflect the duration of this cell cycle, as the early portion of this period includes sperm capacitation, egg penetration, activation, and completion of meiosis II, none of which are true features of a cell cycle. According to these authors, the first cell cycle may be more appropriately timed from the point of second polar body extrusion, as the nuclear composition is $2 \mathrm{C}$ after this time. The first cell cycle can therefore be divided into 3 distinct phases: (i) formation of male and female pronuclei; (ii) DNA synthesis; and (iii) onset of mitosis and cleavage.

When the time of polar body extrusion is taken into account, the duration of the first cell cycle is 20-24h (Eyestone \& First 1988). Cleavage to the 4- and 8-cell stages occurs at approximately $36-50$ and $56-64 \mathrm{~h}$ post-fertilization, respectively. When the mean time period for these cleavage stages are considered, the second and third cell cycles are 13 and $14 \mathrm{~h}$ long, respectively (Barnes \& Eyestone 1990). Cleavage to the 16-cell stage occurs at approximately $80-86 \mathrm{~h}$ post-fertilization with a fourth cell cycle duration of 21-30h (Hamilton \& Laing 1946, Sirard \& Lambert 1985).

\section{In vitro data}

Barnes \& Eyestone (1990) have provided data on the relative lengths of the first 3 cell cycles of bovine embryos generated by IVM/IVF techniques. According to these authors, the total length of the first cell cycle is $28 \mathrm{~h}$. DNA 
synthesis begins at $16 \mathrm{~h}$ post-insemination (hpi) and lasts for $8 \mathrm{~h}$, until $24 \mathrm{~h}$ pi. S phase is followed by a 4-6h G2 phase. The earliest chromosomal condensation is observed at 26$28 \mathrm{~h} \mathrm{pi}$, with first cleavages appearing at $28 \mathrm{~h}$ pi. In most zygotes, pronuclear formation is underway by $10 \mathrm{~h}$ pi. In mice, sheep and cattle, the first cell cycle is long relative to other cell cycles under maternal control (Smith \& Johnson 1986, Barnes 1988, Crosby et al. 1988).

The second cell cycle is considerably shorter than the first, with an overall duration of $12 \mathrm{~h}$. The most striking feature of this cell cycle is the absence of G1. DNA synthesis begins immediately after mitosis and lasts for $8 \mathrm{~h}$. S phase is followed by a rather brief G2 (maximum $2 \mathrm{~h}$ ) and an $\mathrm{M}$ phase of $2 \mathrm{~h}$. As in the first cell cycle, chromosome condensation begins 2-4h prior to cytokinesis.

The third cell cycle presents some difficulties in calculating total duration due to asynchronous cleavage to the fourth cell cycle. Earliest cleavages (i.e. from 4- to 8-cell stage) are observed $9 \mathrm{~h}$ post-initial cleavage (i.e. post-cleavage from 1 - to 2-cell) with the last occurring $6 \mathrm{~h}$ later. The third cell cycle lacks a detectable G1 phase. $S$ phase lasts for $8 \mathrm{~h}$ and is in some blastomeres followed almost immediately by chromosomal condensation, while in others a G2 phase appears lasting up to $6 \mathrm{~h}$. The variations in cell cycle length manifested in the asynchronous cleavage among 4-cell blastomeres are due solely to variations in the length of G2.

\section{Culture conditions in vitro}

Developmental block

It is widely recognized that early embryos from many mammalian species exhibit arrested development at various species-specific stages when cultured in vitro. These developmental blocks are artifacts of the in vitro culture environment. In the majority of cases, these developmental blocks appear to correlate with the onset of embryonic transcription. In species that do not exhibit such overt blocks to development (e.g. primates and rabbits), development in vitro is still restricted due to suboptimal culture conditions, as manifested by reduced development to advanced (morula/blastocyst) stages, prolonged cell cycle times, and/or diminished viability.

Bovine embryos cultured in vitro with typical methods arrest during the fourth cell cycle of development, a phenomenon described as the '8- to 16-cell block'. It is also during the fourth cell cycle in cattle that the embryonically controlled developmental program is initiated, as evidenced by the onset of transcriptional dependency (Barnes 1988), changes in nucleolar structure (King et al. 1988, Kopecny et al. 1989), and major shifts in protein synthetic patterns of the embryo (Frei et al. 1989).

\section{Coculture systems}

In order to overcome the 8- to 16-cell block observed in cattle embryos, various somatic cell supplements have been added to culture medium. A typical coculture system involves placing embryos either in a cell's suspension or on top of cells in a monolayer. Examples of such systems include bovine oviductal epithelial cells (BOEC) (Fukui \& Ono 1988, Lu et al. 1988, Eyestone \& First 1989, Wiemer et al. 1991), granulosa cells (Goto et al. 1988, Tan \& Lu 1990, Wiemer et al. 1991), cumulus cells (Goto et al. 1990, Kajihara et al. 1990, Mermillod et al. 1992), trophoblastic vesicles ( $\mathrm{Ca}$ mous et al. 1984, Heyman et al. 1987), uterine endometrial cells/fibroblasts (Wiemer et al. 1987, Pool et al. 1988, Kajihara et al. 1991) and amniotic sac cells (Aoyagi et al. 1989).

\section{Culture without somatic support}

Various authors have reported on the culture of bovine embryos in the absence of somatic 
support. Bavister et al. (1992) demonstrated that bovine IVM/IVF embryos can develop in the absence of serum or other protein, and without the use of somatic cell coculture, with no obvious block at the 8- to 16- cell stages. Moreover, they found that conditioning the medium with oviduct cell coculture did not improve development. Their results support the view that the block to development is indeed an artifact of the in vitro culture environment and is caused by some component(s) of the culture medium. The authors further suggest that coculture may overcome the block by removing such inhibitory component(s).

\section{Number of embryos per unit volume}

In vitro, the culture conditions differ in many respects to those in the oviducts. Embryos are cultured in relatively large volumes compared to the sub-microlitre volumes of fluid present in the reproductive tract. Any autocrine factor(s) produced by the embryos during development will therefore be greatly diluted out in culture and have minimal, if any, effect. Various authors have demonstrated the beneficial effect of culturing embryos in sufficient densities to overcome this dilution effect for mouse (Canesco et al. 1991, Quinn et al. 1991) as well as bovine embryos (Palma et al. 1992).

\section{Rate of development}

According to Barnes \& Eyestone (1990), the rate of cleavage of in vivo and in vitro cultured bovine embryos is similar up to the 8-cell stage, but the cleavage past the $8-16$ cell stage is very sensitive to environmental conditions.

It is clear that bovine embryos produced in vitro may vary widely, both in their quality and rate of development. Although bovine oocyte maturation is relatively synchronous with approximately $85 \%$ of oocytes reaching metaphase II after $24 \mathrm{~h}$ in culture, the time of first cleavage after IVF may extend over a 24 to
$48 \mathrm{~h}$ period. The initial cleavage divisions of the fertilized ovum are critical for its developmental capacity. Various reports in recent years point to the fact that it is the fastest developing embryos in vitro which are most likely to be comparable to their in vivo counterparts. Dominiko \& First (1992) concluded that oocytes that had polar bodies extruded earlier during maturation are more likely to develop into blastocysts, and suggested that by combining the use of $\mathrm{LH}$ in the maturation medium and selecting for the first polar body, one could improve selection of developmentally competent oocytes. Similarly, Van der Westerlaken et al. (1992) observed that oocytes that had abstricted their first polar body at 16 or $20 \mathrm{~h}$ of in vitro culture displayed higher cleavage and morula/blastocyst rates than their counterparts without a polar body. Plante \& King (1992) undertook a study to determine whether the length of time between insemination and cleavage is related to the embryo's subsequent developmental potential and hatching in vitro. Their results showed that most zygotes cleave between 24 and $48 \mathrm{~h}$ pi. Embryos that were at the 2-cell stage by $30 \mathrm{~h}$ pi gave the highest rate of blastocysts $(65.7 \%)$ and hatching $(50.9 \%)$.

Van Soom et al. (1992) studied the relationship between the interval from insemination to the time of first cleavage and the compaction rate of bovine IVM/IVF/IVC embryos. They found that developmentally competent embryos were characterized by a rapid cleavage rate in the first 3 cell cycles and by an extended 8- to 16-cell stage. Such embryos were found to reach the 2 -cell stage at $36 \mathrm{~h}$ pi and to become compacted at the 32-cell stage, some 126-138h pi.

Personal observations on the rate of development following IVF would agree with these findings. In this author's experience, the cell stage reached by $48 \mathrm{~h}$ pi (at which time cleav- 
age rate is routinely assessed) can be used as an indicator of developmental potential ( $\mathrm{Lo}$ nergan et al. 1992). Eggs which have progressed beyond the 4-cell stage by $48 \mathrm{~h}$ pi consistently give rise to a significantly higher number of blastocysts than those at earlier cell stages. Also, eggs that are still at the 2-cell stage at $48 \mathrm{~h}$ pi are, in the vast majority of cases, destined to degenerate without completing preimplantation development to the blastocyst stage.

With regard to viability in relation to speed of development, the report of Jiang et al. (1992) highlighted the existence of variation in cell numbers in different grades of blastocysts derived from IVM/IVF/IVC and indicated that later developing blastocysts are of poorer quality as judged by cell number. It would appear that the day-7 blastocyst produced in vitro is a more viable entity than one which does not reach this stage until 8 or 9 days post-insemination.

\section{Sex-Related differences in developmental rate}

There is evidence that male cleavage stage embryos develop more rapidly than do females in the mouse (Tsunoda et al. 1985) and in cattle (Avery 1989, Avery et al. 1991, Xu et al. 1992). In the study of Avery et al. (1991), IVF embryos were karyotyped at days 7 and 8 post-insemination. The results showed that the percentage of males (sex ratio) was dependent on the developmental stage. At day 7, among expanded blastocysts (the most advanced embryos), the sex ratio was $100 \%$, with $89 \%$ for expanding blastocysts, $75 \%$ for blastocysts and $40 \%$ for young blastocysts. For embryos karyotyped at day 8 , the sex ratio was $20 \%$. The authors concluded that the apparent relationship between sex and developmental rate could be used as a method for noninvasive prenatal sexing of in vitro fertilized embryos.

Berg et al. (1992) reported no significant dif- ference in the distribution of males and female newborn calves after transfer of advanced (blastocyst) or less advanced (morula) embryo stages of the same chronological age. The authors suggest that the difference in sex ratio between preimplantation embryos and calves at birth may be due to greater foetal mortality for males.

\section{Cell numbers}

Objective parameters on which to base the evaluation of embryos can take various forms. One such parameter is the assessment of the number of cells constituting the embryo. The developmental heterogeneity of bovine embryos results in variability in cell numbers at the blastocyst stage. Much interest in the evaluation of cattle embryos relates to the comparison of cell numbers between those cultured in vitro and those produced in vivo. There is now clear evidence to support the view that many cattle embryos cultured in vitro do not have the same number of cells at the blastocyst stage as embryos cultured in vivo (Wurth et al. 1988, Eyestone \& First 1989, Iwasaki et al. 1990, Fukui et al. 1991, Xu et al. 1992). It has been suggested that the lower cell numbers observed in in vitro-produced embryos may be due to the pattern of cell death within an embryo and lower metabolic activity (Duby et al. 1993).

There are also now many studies in the literature which suggest that it is possible to produce bovine embryos in vitro with cell numbers comparable to their in vivo counterparts (Greve et al. 1992, Jiang et al. 1992, Shamsuddin et al. 1992). It would appear that if proper attention is paid to oocyte/embryo selection and account is taken of rate of development, in vitro produced embryos can be of similar quality to those produced in vitro with regard to cell number. However, whether cell number per se as opposed to the cell number in the inner cell 
mass can be used as a reliable parameter on which to predict further developmental competence is still unclear (Greve et al. 1993).

\section{Factors affecting development}

\section{Epigenetic factors}

In addition to being controlled by the programme encoded in the genome, the development of preimplantation embryos is regulated by the external milieu, i.e. constituents of the reproductive tract secretions in vivo or of the culture medium in vitro. A wide variety of these epigenetic factors, including ions, energy substrates, amino acids, vitamins, growth factors, and hormones, most likely play important roles in early development. There is, however, relatively little knowledge of how such factors might influence cleavage and differentiation of preimplantation embryos. It is beyond the scope of this article to give a thorough account of the nutritional requirements of the early embryo, and the reader is referred to various reviews which have been published in recent years (Leese 1991, Rieger 1992).

\section{Role of growth factors}

The use of reverse transcriptase-polymerase chain reaction (RT-PCR) technology (Rappolee et al. 1990) for detecting mRNAs from small numbers of embryos has made it clear that growth factors or cytokines and/or their receptors are present in the oviduct and the uterus, as well as in the embryos themselves. While molecular biological studies indicate the presence of numerous growth factors in and around the embryo, very little is known about their function in mammalian embryos. In the work of Watson et al. (1992) involving bovine embryos produced by IVM/IVF/IVC techniques and encompassing a developmental series from 1-cell zygotes to hatched blastocysts, the patterns of gene expression for several growth factor ligand and receptor genes were determined. Transcripts for transforming growth factor- $\alpha$ (TGF- $\alpha)$ and platelet-derived growth factor (PDGF-A) were detected in all preimplantation bovine stages as observed in the mouse. Transcripts for TGF- $\beta$ and insulinlike growth factor (IGF-II) and the receptors for PDGF- $\alpha$, insulin, IGF-I, and IGF-II were also detectable throughout bovine preimplantation development, suggesting that these mRNAs are products of both the maternal and the embryonic genomes in the cow, whereas in the mouse they are present only following the activation of the embryonic genome at the 2cell stage (Rappolee et al. 1989). In contrast to the mouse embryo, IGF-I mRNA was detected within preimplantation bovine embryos. Basic fibroblast growth factor (bFGF) is a maternal message in the bovine embryo, since it is only detectable up until the 8-cell stage. Bovine trophoblast protein (bTP, a member of the interferon gene family) mRNA was detectable within day 8 bovine blastocysts. As was observed in the mouse, the transcripts for insulin, EGF or nerve growth factor (NGF) were not detectable in any bovine embryo stage.

Although many of the same growth factors and receptors are expressed in both murine and bovine embryos, the embryonic stages at which transcripts can be detected are distinctly different. As suggested by Watson et al. (1992), this pattern may correlate with the later stage of bovine embryonic genome activation compared with that of the mouse, in as much as these gene products may be important at even the very early stages of cleavage, and it may therefore be necessary for the mRNAs encoding these factors to be included in the maternal mRNA pool in bovine embryos, so that they are present before the maternal-zygotic transition.

\section{Growth factors and in vitro culture}

Addition of physiological levels of growth factors from the insulin gene family of peptides, 


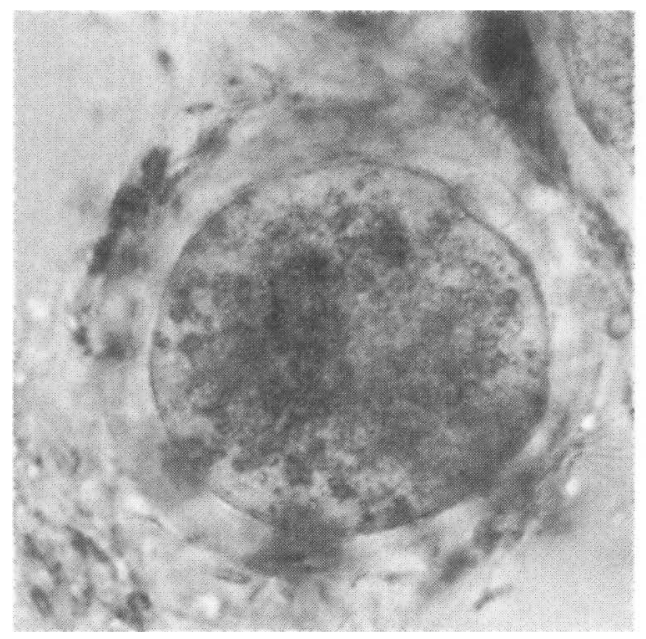

Figure 1. In vitro-matured bovine oocyte at insemination. Note presence of first polar body in perivitelline space.

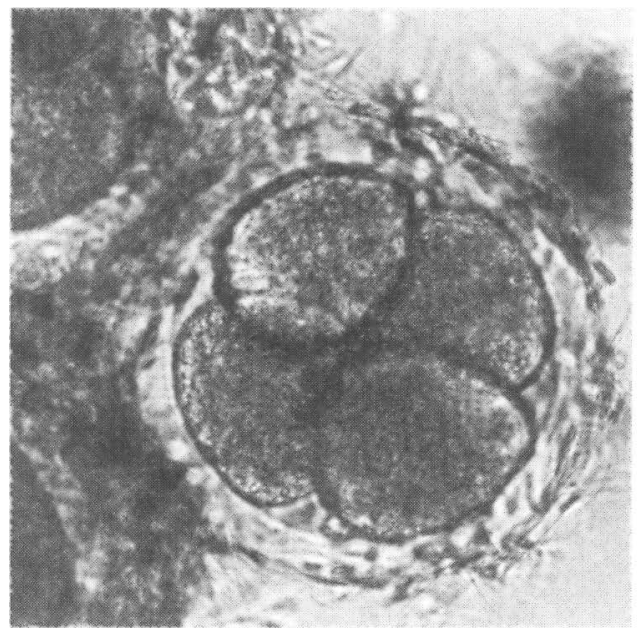

Figure 3. Four-cell embryo 48 hours post-insemination.

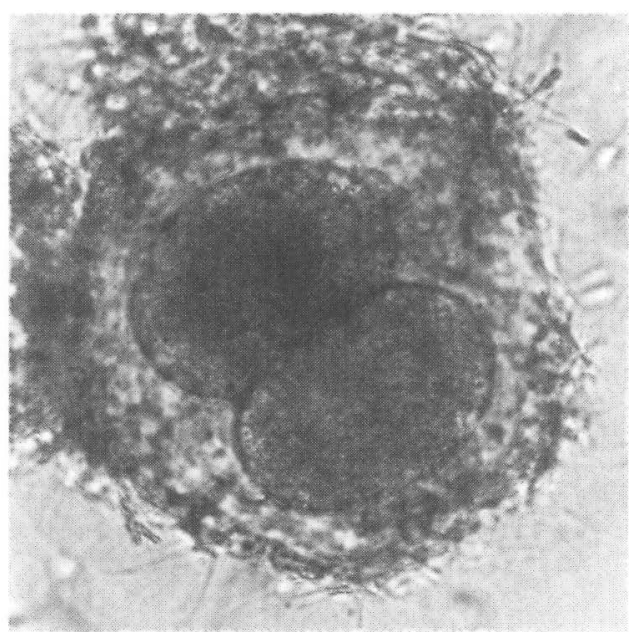

Figure 2. Two-cell embryo 48 hours post-insemination.

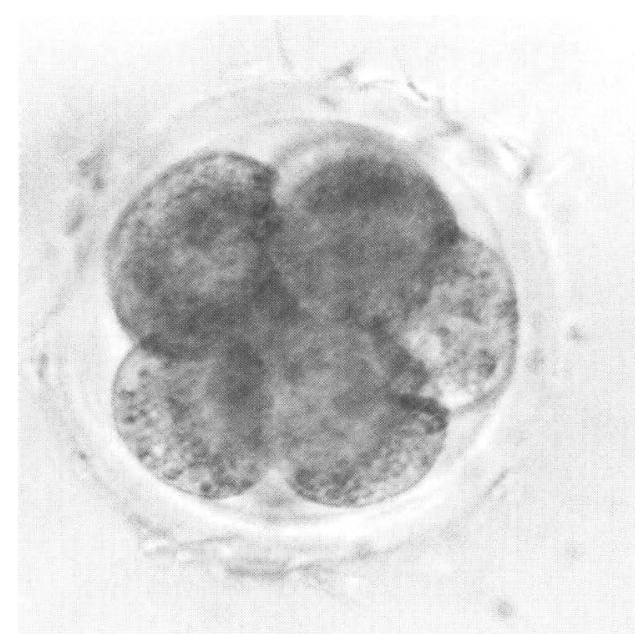

Figure 4. Eight-cell embryo 48 hours post-insemination. 


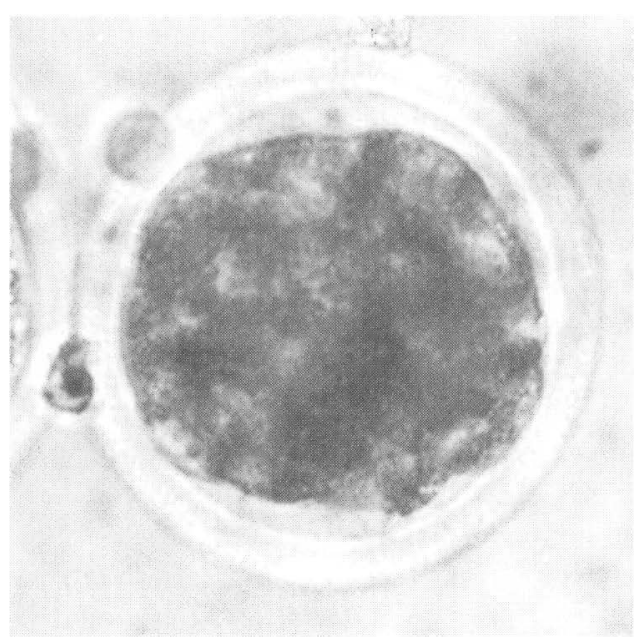

Figure 5. Compact morula 6 days post insemination.

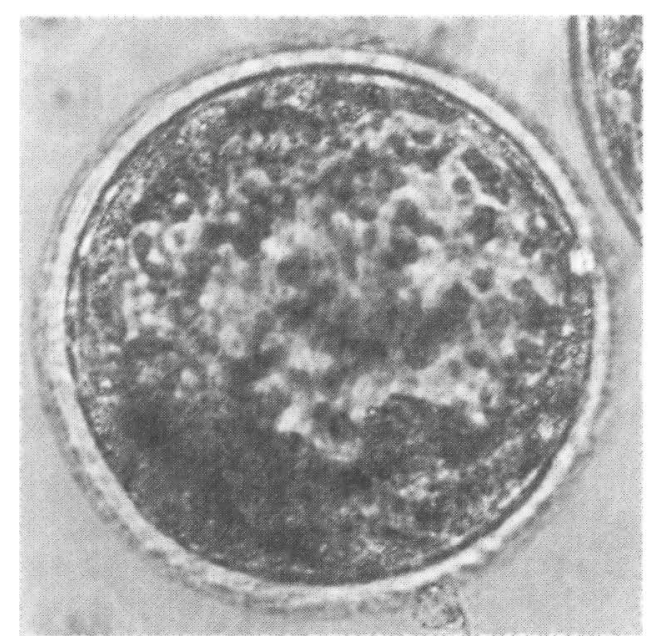

Figure 7. Expanding blastocyst 8 days post-insemination.

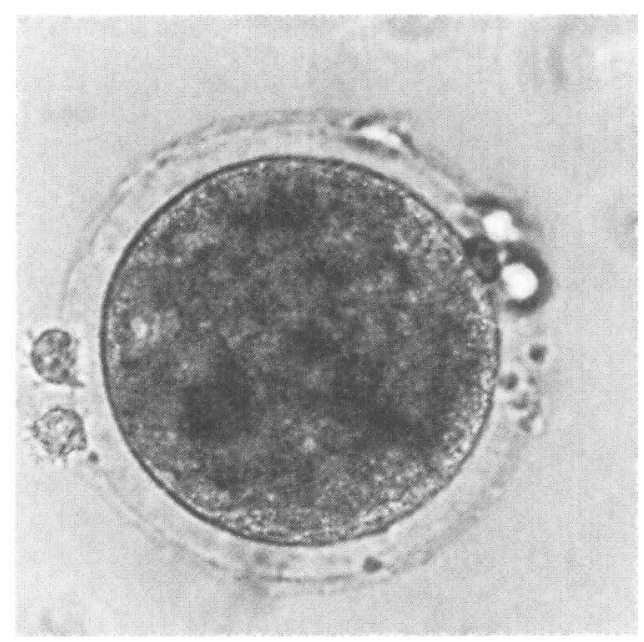

Figure 6. Early blastocyst 6 days post-insemination.

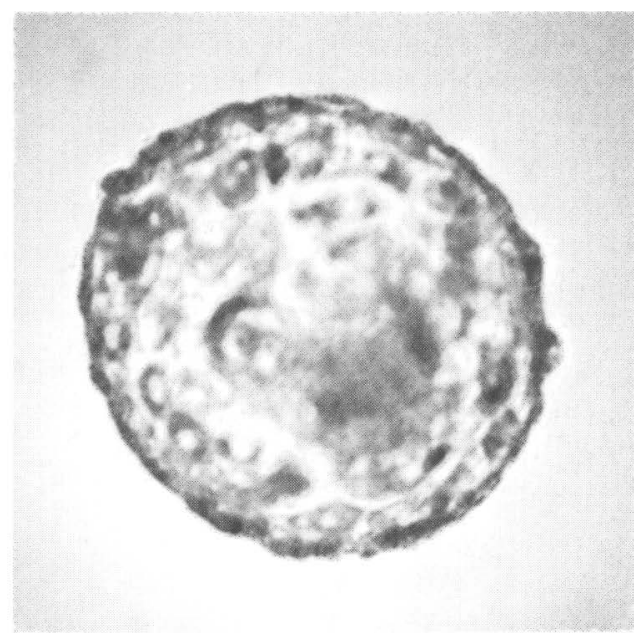

Figure 8. Hatched blastocyst 9 days post-insemination. 
the epidermal growth factor (EGF) gene family and the transforming growth factor- $\beta$ (TGF- $\beta$ ) gene family to the culture medium of early mouse embryos results in a broad range of effects that include stimulation of RNA and protein synthesis, increased rate of cell division, increase in the cell number in blastocysts, and increase in the percentage of cultured embryos that hatch from the zona pellucida (Harvey \& Kaye 1988, 1990, 1991, Heyner et al. 1989, Wood \& Kaye 1989, Rappolee et al. 1990, Paria and Dey 1990, Werb 1990). Thus there is strong supporting evidence that these molecules play important roles in the program of development of the preimplantation mouse embryo. However, as pointed out by Watson et al. (1992), little is known about the expression of these gene sets during preimplantation development of other mammalian species.

Supplementation of culture media of bovine embryos with various growth factors has been reported recently (Larson et al. 1992, Flood et al. 1993, Thibodeaux et al. 1993, Shamsuddin et al. 1993, Yang et al. 1993). As suggested by Thibodeaux et al. (1993), it is possible that the embryotrophic effects of coculture systems are mediated via the secretion of 1 or more growth factors. PDGF has been detected in bovine oviductal secretions (Gandolfi et al. 1991). In addition, Larson et al. (1992) reported that the addition of $1 \mathrm{ng} \mathrm{PDGF} / \mathrm{ml}$ to the culture medium induced bovine embryos to develop beyond the 8-16 cell stage. These authors noted that PDGF activated specific proto-oncogenes and reduced the duration of the 4th cell cucle (Larson et al. 1992). Other growth factors, such as bFGF amd TGF $\alpha$ appear to play more significant roles at the 5 th cell cycle (Larson et al. 1992), but TGFß may also act synergistically with EGF to increase the frequency of hatched blastocysts in in vitro produced bovine embryos (Keefer 1992).
Thibodeaux et al. (1993) studying the role of PDGF in early bovine embryo development suggested that at least part of the beneficial effect of coculture of bovine embryos with oviduct epithelium is due to PDGF.

In the study of Yang et al. (1993), all growth factors tested were shown to stimulate the development of bovine IVM/IVF embryos to the blastocyst stage. The degree of stimulation was related to dose and, as suggested by the authors, probably to the media composition. Despite these encouraging results, other authors have not been able to find a positive effect following the addition of growth factors to the culture medium of in vitro produced bovine embryos (Flood et al. 1993).

It is certain that our knowledge of growth factor regulation of preimplantation development is far from complete. While experiments in which growth factors are randomly added to culture media and assayed by measuring the percentage of embryos reaching the blastocyst stage (as cited above) have some use in elucidating the role of such factors, more comprehensive approaches involve the mapping of the anatomy of ligand and receptor, characterization of receptor binding and intracellular signalling, and the use of specific endpoints of biochemical and morphological differentiation to determine function in vitro (Kane et al. 1992).

\section{Concluding Remarks}

Efficient in vitro techniques as a low cost source of eggs and early embryos are of considerable value for research purposes and for the development of new biotechnologies of agricultural interest. In recent years, substantial progress has been made in the development of procedures for IVM/IVF/IVC of bovine embryos. However, further improvements are necessary in the system in order to maximize embryo production. 
The predominant approach in the production of bovine embryos in vitro involves coculture with somatic cells using a complex culture medium containing blood serum. Although many studies have utilized such coculture to support development of embryos through the 8- to 16-cell block, this undefined culture milieu makes it difficult to examine key epigenetic factors regulating embryo development. Elucidation of these factors is essential for the formation of optimal culture media based on the actual requirements of embryos. The development of such a defined culture medium would eliminate the chemical heterogeneity introduced by serum and somatic cells to the medium and allow the importance of individual components to be investigated.

By applying such culture methods to the production of preimplantation bovine embryos from slaughterhouse ovaries, it should be possible to produce large numbers of viable bovine embryos under controlled and reproducible conditions, which would represent a new comparative resource for the study of early preimplantation development.

\section{References}

Aoyagi Y, Fukui Y, Iwazumi Y, Urakama M, Minegishi Y, Ono H: Effects of culture system on development of in vitro fertilized bovina ova into blastocysts. Theriogenology 1989, 31, 168 .

Avery $B$ : Impact of asynchronous ovulations on the expression of sex-dependent growth rate in bovine preimplantation embryos J. Reprod. Fert. 1989, 87, 627-631.

Avery $B$, Madison $V$, Greve T: Sex and development in bovine in vitro fertilized embryos. Theriogenology 1991, 35, 953-963.

Barnes FL: Characterization of the onset of embryonic control and early development in the bovine embryo. Ph.D. Thesis, University of Wisconsin-Madison 1988.

Barnes FL, Eyestone WH: Early cleavage and the maternal transition in bovine embryos. Theriogenology 1990, 33, 141-152.

Bavister BD, Rose-Hellekant TA, Pinyopummintr T:
Development of in vitro matured/in vitro fertilized bovine embryos into morulae and blastocysts in defined culture media. Theriogenology 1992, 37, 127-146.

Berg U, Reichenbach HD, Liebrich J, Brem G: Sex ratio of calves born after transfer of in vitro produced embryos. Theriogenology 1992, 37, 191.

Betteridge KJ, Flechon JE: The anatomy and physiology of preattachment bovine embryos. Theriogenology 1988, 29, 155-187.

Camous S, Heyman Y, Meziou W, Menezo Y: Cleavage beyond the block stage and survival after transfer of early bovine embryos cultured with trophoblastic vesicles. J. Reprod. Fert. 1984, 72, 479-485.

Canseco RS, Sparks AET, Pearson RE, Gwazdauskas $F C$ : Effect of microdrop size and number of embryos per microdrop on early murine embryo development. Serono Symposium on Preimplantation Embryo Development. 1991, Abstract Volume, 29.

Crosby IM, Gandolfi F, Moor RM: Control of protein synthesis during early cleavage of sheep embryos. J. Reprod. Fert. 1988, 82, 769-775.

Dominiko T, First NL: Kinetics of bovine oocyte maturation allows selection for developmental competence and is affected by gonadotropins. Theriogenology 1992, 37, 203.

Dubicella T, Anderson P: Cell shape and membrane changes in the eight-cell mouse embryo. Prerequisites for morphogenesis of the blastocyst. Dev. Biol. 1975, 47, 45.

Duby RT, Dobrinsky JR, Robl JM, Overstrom EW, Boland MP, Bagusi A, Lonergan P, Roche JF: Development rate, esterase activity and death of cells in in vitro and in vivo produced bovine embryos. Theriogenology 1993, 39, 210.

Eyestone WH, First NL: Cell cycle analysis of early bovine embryos. Theriogenology 1988, 29, 243.

Eyestone WH, First NL: Co-culture of early cattle embryos to the blastocyst stage with oviducal tissue or in conditioned medium. J. Reprod. Fert. 1989, 85, 715-720.

Flood MR, Gage TL, Bunch TD: Effect of various growth-promoting factors on preimplantation bovine embryo development in vitro. Theriogenology 1993, 39, 823-833.

Frei RE, Schultz GA, Church RB: Qualitative and quantitative changes in protein synthesis occur at the 8-16 cell stage of embryogenesis in the cow. J. Reprod. Fert. 1989, 86, 637-641.

Fukui Y, Ono H: In vitro development to blastocyst 
of in vitro matured and fertilized bovine oocytes. Vet. Rec. 1988, 122, 282-283.

Fukui Y, McGowan LT, James RW, Pugh PA, Tervit $H R$ : Factors affecting the in-vitro development to blastocysts of bovine oocytes matured and fertilized in vitro. J. Reprod. Fert. 1991, 92, 125-131.

Gandolfi F, Brevini TAL, Modina S, Lauria A: Detection and characterization of a growth factor in bovine oviduct secretions. J. Reprod. Fert. 1991, Abstract Series 7, Abstract 6.

Goto K, Kajihara Y, Kosaka S, Koba M, Nakanishi Y, Ogawa K: Pregnancies after co-culture of cumulus cells with bovine embryos derived from in vitro fertilization of in vitro matured follicular oocytes. J. Reprod. Fert. 1988, 83, 753-758.

Goto K, Kinoshita A, Takuma Y, Ooe N, Ogawa K: In vitro development of bovine oocytes collected from ovaries of individual cows after in vitro fertilization. Japan. J. Anim. Reprod. 1990, 36, 110113.

Greve T, Loskutoff NM, Buckrell BC, Christian CR, Leibo SP, Betteridge KJ: Morphology and freezing tolerance of in vitro derived bovine embryos after culture in vivo or in vitro. 5eme colloque Franco-Tchecoslovaque sur la reproduction des animaux domistiques. Jouy-en-Josas, France. 1992, 36.

Greve $T$, Avery $B$, Callesen $H$ : Viability of in-vivo and in-vitro produced bovine embryos. Reprod. Dom. Anim. 1993, 28, 164-169.

Hamilton WJ, Laing JA: Development of the egg of the cow up to the stage of blastocyst formation. J. Anat. 1946, 80, 194-204.

Harvey $M B$, Kaye $P L$ : Insulin stimulates protein synthesis in compacted mouse embryos. Endocrinology 1988, 122, 1182-1184.

Harvey $M B$, Kaye $P L$ : Insulin increases the cell number of the inner cell mass and stimulates morphological development of mouse blastocysts in vitro. Development 1990, 110, 963-967.

Harvey $M B$, Kaye PL: Mouse blastocysts respond metabolically to short-term stimulation by insulin and IGF-I through the insulin receptor. Mol. Reprod. Dev. 1991, 29, 253-258.

Heyman Y, Menezo Y, Chesne P, Camous S, Garnier V: In vitro cleavage of bovine and ovine early embryos: improved development using co-culture with trophoblastic vesicles. Theriogenology 1987, 27, 59-68.

Heyner S, Rao LV, Jarett L, Smith RM: Preimplantation mouse embryos internalize maternal insulin via receptor-mediated endocytosis. Pattern of uptake and functional correlations. Dev. Biol. 1989, 134, 48-58.

Hyafil F, Morello D, Babinet C, Jacob F: A cell surface glycoprotein involved in embryonal carcinoma cells and cleavage stage embryos. Cell 1980, 21, 927-934.

Hyttel P, Greve T, Callesen H: Ultrastructure of in vivo fertilization in superovulated cattle. J. Reprod. Fert. 1988, 82, 1-13.

Iwasaki S, Yoshiba N, Ushijima H, Watanabe S, Nakahara $T$ : Morphology and proportion of inner cell mass of bovine blastocysts fertilized in-vitro and in-vivo. J. Reprod. Fert. 1990, 90, 279-284.

Jiang HS, Wang WL, Lu KH, Gordon I: Effects of PMSG, insulin, osmolarity and oestrous cow serum on development of IVF early bovine embryos cultured on granulosa cell monolayers. Theriogenology 1990, 33, 258.

Jiang HS, Wang WL, Lu KH, Gordon I, Polge C: Examination of cell numbers of blastocysts derived from IVM, IVF and IVC of bovine follicular oocytes. Theriogenology 1992, 37, 229.

Kajihara Y, Kometani N, Kobayashi S, Shitanaka Y, Koshiba Y, Hishiyama K, Shiraiwa K, Goto K: Pregnancy rates and births after coculture of cumulus cells with bovine embryos derived from in vitro fertilization of in vitro matured follicular oocytes. Theriogenology 1990, 33, 264.

Kajihara Y, Kometani N, Kobayashi S, Shitanaka Y, Goto $K$ : Pregnancy by bovine blastocysts developed in coculture with cumulus/uterine endometrial cells after in vitro fertilization. Japan. J. Anim. Reprod. 1991, 37, 177-184.

Kane MT: Control of growth in preimplantation embryos. Ir. J. Med. Sci. 1990, 160, 17-22.

Kane MT, Carney EW, Ellington JE: The role of nutrients, peptide growth factors and co-culture cells in the development of preimplantation embryos in vitro. Theriogenology 1992, 38, 297-313.

Keefer CL: Development of in vitro produced bovine embryos cultured individually in a simple medium: effects of EGF and TGFB1. Theriogenology 1992, 37, 236 (Abs).

King WA, Niar A, Chartrian I, Betteridge KJ, Guay $P$ : Nucleolus organizer regions and nucleoli in preattachment bovine embryos. J. Reprod. Fert. 1988, 82, 87-92.

Kopecny V, Flechon JE, Camous S, Fulka J, Jr: Nucleogenesis and the onset of transcription in the eight-cell bovine embryo: Fine structural and autoradiographic study. Mol. Reprod. Dev. 1989, 1, 79-90. 
Larson RC, Ignotz GG, Currie WB: Transforming growth factor $B$ and basic fibroblast growth factor synergistically promote early bovine embryo development during the fourth cell cycle. Mol. Reprod. Dev. 1992, 33, 432-435.

Leese HJ: Metabolism of the preimplantation mammalian embryo. Oxford Rev. Reprod. Biol. 1991, 13, 35-72.

Linares T, King WA: Morphological study of the bovine blastocyst with phase contrast microscopy. Theriogenology 1980, 14, 123-133.

Lonergan P, Fair T, Gordon I: Effect of time of transfer to granulosa cell monolayer and cell stage at 48 hours post-insemination on bovine oocyte development following IVM/IVF/IVC. 8th Scientific Meeting of the European Embryo Transfer Association, Lyon 11-12th September, 1992, 136.

Lu KH, Gordon I, Chen HB, Gallagher M, McGovern $H$ : Birth of twins after transfer of cattle embryos produced by in vitro techniques. Vet. Rec. 1988, 122, 539-540.

Mannaerts $B M L$ : Cytological parameters for rating bovine embryo quality. Cur. Top. Vet. Med. Anim. Sci. 1986, 34, 216-222.

Mermillod P, Boccart C, Wils C, Massip A, Dessy F: Effect of oviduct-conditioned medium and of cumulus cells on bovine embryo development in vitro. Theriogenology 1992, 37, 256.

Motlik J, Kubelka M: Cell-cycle aspects of growth and maturation of mammalian oocytes. Mol. Reprod. Dev. 1990, 27, 366-375.

Palma GA, Clement-Sengewald A, Berg U, Brem G: Role of the embryo number in the development of in vitro produced bovine embryos. Theriogenology 1992, 37, 271.

Paria BC, Dey SK: Preimplantation embryo development in vitro: Cooperative interactions among embryos and role of growth factors. Proc. Natl. Acad. Sci. USA 1990, 87, 4756-4760.

Picard L, Greve T, King WA, Betteridge KJ, HolmJorgensen $P$ : Bisection of post-compaction bovine embryos: the difference in viability between the two monozygotic halves. Acta. Vet. Scand. 1986, 27, 33-48.

Plante L, King WA: Effects of time to first cleavage on hatching rate of bovine embryos in vitro. Theriogenology 1992, 37, 274.

Pollard JW, Xu KP, Rorie R, King WA, Betteridge KJ: Influence of various oviductal epithelial cell culture on the development of early cleavage bovine embryos in vitro. Theriogenology 1988, 31, 239.
Pool SH, Rorie RW, Pendlton RJ, Menino AR, Godke RA: Culture of early stage bovine embryos inside day-13 and day-14 precultured trophoblastic vesicles. Anns. New York Acad. Sci. 1988, 541, 407-418.

Quinn P. Hirayama T, Marrs RP: Cooperative interaction among mouse zygotes cultured in proteinfree medium: blastocyst development and hatching. Serono Symposium on Preimplantation Embryo Development 1991, Abstract Vol., II-35, 68.

Rappolee DA, Wang A, Mark D, Werb Z: Novel method for studying mRNA phenotypes in single or small numbers of cells. J. Cell Biochem. 1989, 39, 1-11.

Rappolee DA, Sturm KS, Schultz GA, Pederson RA, Zerb Z: The expression of growth factor ligands and receptors in preimplantation embryos. UCLA Symposia on Molecular and Cellular Biology, New Series 1990, 117, 11-25.

Rieger D: Relationships between energy metabolism and development of early mammalian embryos. Theriogenology 1992, 37, 75-93.

Rose TA, Bavister BD: Effect of oocyte maturation medium on in vitro development of in vitro fertilized bovine embryos. Mol. Reprod. Dev. 1992, 31, 72-77.

Shamsuddin M, Larsson B, Gustafsson H, Gustari S, Bartolome J, Rodriguez-Martinez H: Comparative morphological evaluation of in vivo and in vitro produced bovine embryos. 12th International Congress on Animal Reproduction 1992, 3, 1333-1335.

Shamsuddin M, Larsson B, Rodriguez-Martinez $H$ : Culture of bovine IVM/IVF embryos up to the blastocyst stage in defined medium using insulin, transferrin and selenium or growth factors. Reprod. Dom. Anim. 1993, 28, 209-210.

Sirard MA, Lambert RD: In vitro fertilization of bovine follicular oocytes obtained by laparoscopy. Biology of Reproduction 1985, 33, 487-494.

Smith RKW, Johnson MH: Analysis of the third and fourth cell cycles of mouse early development. J. Reprod. Fert. 1986, 76, 393-399.

Tan SJ, Lu KH: Effects of different oestrous cycle stages of ovaries and sizes of follicles on generation of IVF early embryos. Theriogenology 1990, $33,335$.

Thibodeaux JK, Del Vecchio RP, Hansel W: Role of platlet-derived growth factor in development of in vitro matured and in vitro fertilized bovine embryos. J. Reprod. Fert. 1993, 98, 61-66. 
Tsunoda Y, Todunaga T, Sugie T: Altered sex ratio of live young after transfer of fast and slow-developing mouse embryos. Gamete Research 1985 , 12, 301-304.

Van Soom A, Van Vlaenderen I, Mahmoudzadeh AR, Deluyker $H$, de Kruif $A$ : Compaction rate of in vitro fertilized bovine embryos related to the interval from insemination to first cleavage. Theriogenology 1992, 38, 905-919.

Watson AJ, Hogan A, Hahnel A, Wiemer KE, Schultz $G A$ : Expression of growth factor ligand and receptor genes in the preimplantation bovine embryo. Mol. Reprod. Dev. 1992, 31, 87-95.

Werb Z: Expression of EGF and TGF- $\alpha$ genes in early mammalian development. Mol. Reprod. Dev. 1990, 27, 10-15.

van der Westerlaken LAJ, de Wit AAC, van der Schans A, Eyestone WH, de Boer H: Relationship between kinetics of polar body extrusion and developmental potential of bovine oocytes. 12th Int Congr. on Anim. Reprod., The Hague, The Netherlands 1992. Vol. 1, 384-386.

Wiemer KE, Denniston RS, Amboroski GF, White $K L$, Godke RA: A fetal bovine uterine fibroblast monolayer system for in vitro culture of bovine embryos. J. Anim. Sci. 1987, 65 (Suppl. 1), 53.

Wiemer KE, Watson AJ, Polanski V, McKenna AI, Fick $G H$, Schultz $G A$ : Effects of maturation and co-culture treatments on the developmental capacity of early bovine embryos. Mol. Reprod. Dev. 1991, 30, 330-338.

Wood SA, Kaye PL: Effects of epidermal growth factor on preimplantation mouse embryos. J. Reprod. Fert. 1989, 85, 575-582.

Wurth YA, van ser Zee-Kotting W, Kruip TAM,
Dieleman SJ, Bevers MM: Relation between macroscopic qualification of bovine embryos and number of blastomeres. Proc. 11th Int. Congr. Anim. Reprod. AI, Dublin, Ireland 1988, 3,352 .

Xu KP, Yada BR, King WA, Betteridge KJ: Sex-related differences in developmental rates of bovine embryos produced and cultured in vitro. Mol. Reprod. Dev. 1992, 31, 249-252.

Yang $B K$, Yang $X$, Foote $R H$ : Effect of growth factors on morula and blastocyst development of in vitro matured and in vitro fertilized bovine oocytes. Theriogenology 1993, 40, 521-530.

Younis AI, Brackett BG: In vitro development of bovine oocytes into morulae and blastocysts. Theriogenology 1990, 33, 362.

\section{Sammendrag}

In vitro utvikling av pattedyrembryo er både funksjonelt og tidsmessig dårligere enn embryo som utvikler seg naturlig i de hunnlige kjønnsveier. Manglene ved dyrkede embryoner varierer fra lav delingshastighet til fullstendig delingsstopp, som inntrer på bestemte stadier hos mange arter. Forskjellige metoder har blitt brukt for å forhindre denne såkalte blokkering, inklusive kultur av embryo med forskjellige somatiske celler. Til tross for bruk av slike systemer er in vitro utvikling av embryo forsatt ikke sammenlignbart med in vivo utvikling. Til tross for en rekke variasjoner i de benyttede teknikker flater nivået av utviklede morulae/blastocyster ved 25$40 \%$ av inseminerte oocytter i de fleste laboratorier. Det kreves en bedre forståelse av faktorene som styrer embryoets vekst før vi kan håpe å oppnå resultater som kan sammenlignes med forhold in vivo.

(Received October 21, 1993).

Reprints may be requested from: P. Lonergan, INRA, Station de Physiologie de la Reproduction, 37380 Nouzilly, France. Fax: (33) 474277 43. E-mail: Lonergan@tours.inra.fr 